\title{
Caring Power - Coercion as Care
}

\begin{abstract}
Summary
The article analyses the compulsory care of drug misusers in Sweden. An historical analysis of this field of work as a part of the Swedish welfare state highlights historically changing legislations, institutions, understandings and practices. Following Foucault, it is argued that it is impossible to distinguish between power and care and that confusion about coercive care is a result of not acknowledging power. Empirical studies of current social work point to the significance of different institutional settings. The author's study of the Swedish probation service shows that social workers and clients may adopt different positions in relation to each other and that their experiences of the practice of social work depend on the congruence or disparity between these positions. The problematic role of motivation in coercive care is highlighted. While some scholars claim that motivation is not possible in coercive institutions, the author relates motivation to the caring power arguing that social work is always aimed at normality and that care is exercised to achieve normality. The promise of an improved life situation may make people in need of help adapt to the demands of the helper, and the caring power can be seen as a way to provide help for individuals who do not realize that they are in need of care.
\end{abstract}

\section{Compulsory care}

Compulsory care of adult misusers has a long history in Sweden. It is now almost 90 years since the first legislation about compulsory care in this area was introduced. This disciplinary intervention became a part of the process of civilization and was, at the same time, an indication of the democratization of the state and of the social control of individuals. The Swedish historian Björkman (2001) has shown that the idea of compulsory care has not only a long, but also a homogenous history in Sweden.

Björkman studied compulsory care in four different areas between the years 1850 and 1970: epidemic diseases, venereal diseases, mental illness, and addiction to alcohol and drugs. She focused on how coercion was justified in the legislation, and she considered the process of civilization and the process of disciplining to be two different aspects of the same development. All in all, this shows how the conception of mankind evolved with the development of the democratic nation state.

Initially, the main argument for the use of coercion was that the individuals in question were a threat to others and, therefore, a threat to society. Later, the use of coercion became a part of the welfare-state project and was then not only used for the benefit of society but also for the benefit of the individual. During the early twentieth century, the concepts of state and society began to be used interchangeably and were later used synonymously. Compulsory care was legitimized by the idea that society and the individual were connected with each other. Coercion was a 
way of providing help for those in need of care since it protected them, their families and society. The justification for a compulsory care of alcoholics and drug addicts was that the addicts were a danger to themselves and to their surroundings.

Compulsory care of alcoholics and drug addicts has been questioned and discussed since the 1960s. The legislation and the institutions of compulsory care were criticized, but both were maintained. The main reason for the use of coercion is that it should be applied when somebody, as a result of regular misuse of alcohol or drugs, is in need of care to break away from the misuse, and when it is not possible to provide care in any other way. The person in question should also be exposing his physical or mental health to severe danger, or evidently damaging his social situation, or there should be a risk that he is going to harm himself or others seriously (Care of Abusers Act, 1988: 870, §4).

A main task for compulsory care is to motivate a person to agree to continue in voluntary treatment and accept the support offered. Compulsory care is carried out in special institutions which intrude on an individual's personal integrity. Certain rules make it possible to prohibit a person's possession of certain properties, to search his belongings and body, to limit his freedom of movement, and to control his mail and other deliveries (Care of Abusers Act, 1988, p. 870, §31-36). In her Ph.D. thesis, the legal expert Gustafsson stated that this law, the Care of Abusers Act, does not live up to its legislative requirements. As a result of insufficient clarity, it does not protect individuals against discretionary or arbitrary acts (Gustafsson, 2001).

This ambiguity makes it possible to arrange compulsory care in different ways for different persons. It makes it possible to adjust the coercion and the control, as well as the help and care, to cover the need in each specific case. Is that actually happening, or is the ambiguity just an expression of confu- sion? In this article, I shall discuss the problems of understanding coercive care as both support and control and how we may understand what is happening between the individual and the institution. To do so, I shall use the concept of caring power and take a closer look at recent research on social work and compulsory care of drug misusers in Sweden.

\section{Caring power}

This concept was created by the Dutch researcher van Drenth and developed in her joint study with de Haan of two Quaker women in the beginning of the nineteenth century, Elisabeth Fry and Josephine Butler. The study is presented in their book The Rise of Caring Power (1999). Van Drenth and de Haan were inspired by Foucault's concept of pastoral power which they renamed for two reasons: in order to emphasize the double secularization involved and in order to underline the importance of care as a technique of power.

Pastoral power originates from medieval Christianity where it aimed at individual salvation in the hereafter. Later, pastoral power became a promise of well-being in this life. According to Foucault, pastoral power changed around 1800 when the religious aim was replaced by worldly goals such as health, well-being, and security. Van Drenth and de Haan state that in the nineteenth century Protestants made up the forefront of philanthropy and social reform by means of an active Christianity and that in this context the well-being of individuals must, hence, be regarded as connected to religion. Later in the nineteenth century, the secular goals of a caring power gradually replaced the religious goals (van Drenth \& de Haan, 1999, p. 14 ff). Care was carried out by a growing number of social workers, psychologists, educators, and so forth. They gathered knowledge about individuals and about the population as a whole, and this knowledge legitimized the 
objectification resulting from the interventions.

Knowledge-based interventions are a form of the exercise of power. Power, as Foucault (1987) describes it, is neither the possession of a group or a person, nor a question of dominance. Power is a productive principle that is exercised. Van Drenth and de Haan see the Quaker woman Elisabeth Fry's work as a superb example of power in Foucault's sense of the term. Elisabeth Fry carried out what today we would call social work among offenders in London prisons at the beginning of the nineteenth century. She sought the cooperation of the prisoners by offering them a choice. They could either decide to cooperate with her and her plans for them, or they could reject them. If they cooperated, they would be treated well and given opportunities for a better life in and out of prison. Elisabeth Fry laid out her ideas on this subject in one of her works in which she says: "The prisoners are ruled by kindness, chains are therefore unnecessary". (Fry, 1816, quoted in McGowen, 1995, p. 96)

Van Drenth and de Haan also say that while professionals exercise a pastoral power, the caring power can be exercised by professionals as well as by laymen. The basic idea is that the promise of an improved life situation makes people in need of help adapt to the demands of the helper. Obviously, the main idea in the caring power is, "if you do as I tell you to, you will live a better life". This idea of well-being for individuals also implies an idea of well-being for society since helping the needing individuals makes a better society.

In conclusion, I want to emphasize three reasons for using the concept of caring power instead of Foucault's concept of pastoral power although they are based on the same idea. One reason is to avoid the religious connotation in the concept of pastoral power. The second reason is to make it clear that care in itself can be a technique of power.
And the third reason is that the concept of caring power makes it possible to see that the same kind of power can be exercised by professionals as well as by laymen.

From an ideological perspective there is a difference between treatment and punishment. When applied in practice, the ideological concepts of treatment and punishment will be designated support and control, and here they make up two different views on the same actions. The concept of caring power allows no room for a distinction between treatment and punishment or between support and control in practice.

Arguing for the co-existence of support and control means that you have to consider them as different actions. Using the concept of caring power, we have to consider support and control as different ideological interpretations of the same actions. Treatment can be seen as control just as punishment can be seen as help. In order to control the prisoners, Elisabeth Fry offered them hope and respect as well as psychological and material support. These aspects of help and support still constitute the main task of social workers. Social workers do help their clients, but they choose the directions in which the help they provide is leading. This issue is applicable to all kinds of social work. Whether we speak of counseling or coercive care, social work is always aimed at normality. Normality is the ambition of social work regardless of whether this normality is limited by legislation or by norms.

\section{Support and control - an unbreakable unity}

When you ask social workers, or their clients, what help is and what control is, their answers vary widely. What one person describes as support, another will call control. Actions are interpreted in the eye of the beholder. But the interpretation is also created in the relationship between the social worker 
and the client. In my thesis about the Swedish probation service, I found that the stories told by the different performers vary depending on their intentions regarding the contact and the task of the probation service (Svensson, 2001). The social workers and the clients vary in their attitude towards their common task. This variation can be seen not only between the groups but also in each of the two groups of actors.

In his studies of organizations, the sociologist Perrow (1967) adopted two characteristics as his starting point: on the one hand, the degree of standardization and flexibility and, on the other hand, the degree of knowledge of the processed material. By transferring Perrow's idea to social work and modifying the concepts, it has become possible to understand the different interpretations.

Social workers are to a varying degree inclined to regard individual clients as persons, and they are to a varying degree willing to take an active interest in the client. Depending on the social workers' views of the clients and of their duty, they can adopt different positions. These positions arise in their relation with the clients and with the situation. Consequently, these positions are not fixed. New positions are possible in every moment, in every relation.

\section{Degree of individualization}

$\begin{array}{llll} & & \text { High } & \text { Low } \\ & \text { High } & \text { Treaters } & \text { Controllers } \\ \begin{array}{l}\text { Degree of } \\ \text { intervention }\end{array} & \text { Low } & \text { Supporters } & \text { Tired ones }\end{array}$

The treaters like their work and like to work hard. They have a methodological view on social work looking at their client as a person with a history, a present and a future. Together with their client, they would like to examine the client's situation and find proper solutions. The supporters are also interested in their client as a person, but they do not want to do very much. The supporters talk about conversation as the main tool in their work. Talk is therapeutic in itself and, there- fore, the most important thing is to be a good listener. The controllers take the opposite view. According to them, the rules and the laws are crucial, and they talk about their clients in terms of their crimes or other categorical concepts. The tired ones, finally, do what they have to do, but they do not believe in it.

Similarly, the clients can take up different positions depending on their interests in the contact with the social workers and in acting together with them.

Interest in probation-service contacts

\begin{tabular}{llll} 
& & High & Low \\
$\begin{array}{l}\text { Degree of } \\
\text { readiness } \\
\text { for action }\end{array}$ & High & Changers & Resisters \\
\hline & Low & Talkers & Passive ones
\end{tabular}


The changers are happy to have come into contact with the probation service. This contact is an opportunity for change, and they want to do something about their lives. The talkers are also content with the probation service, but they describe it as good because there are people who will listen to them. There is not meant to be a lot of action, but it creates an opportunity to have a social worker interested in them for a while. The resisters will fight hard not to have a close relationship and to keep their distance to the social workers. The passive ones, finally, do what they are told - neither more nor less.

When the parties' attitudes towards each other are similar, their positions are congruous, and when their attitudes differ, their positions are discrepant. Congruous positions accumulate stories about the supportive aspects and discrepant stories accumulate stories about the controlling aspects.

When the stories are based on supportive aspects, we are presented with images of nice people meeting each other and having quite a nice time together, but in different ways. The talkers meeting the supporters will describe the pleasant conversation. The changers and the treaters work actively for the clients towards a common goal. The controllers and the resisters become united in their fight for regulations, both fully sympathizing with the other's actions. And the tired ones and the passive ones become united in their indifference and agree that supervision does not amount to much, really. These congruent positions create a unit where both parties can express themselves.

When the positions are discrepant, the parties describe the action that occurred in other ways. Their views do not result in unity, in an understanding of the other party, and the controlling aspects take over. Changers meeting tired social workers will be disappointed and consider the supervision far from being the help they were hoping for - it was just control after all. Similarly, treaters meeting re- sisters might describe their feelings of frustration that they were not given an opportunity to show their engagement. The clients' resistance could make the social workers lose control over the situation and experience a sense of powerlessness.

Since both power and resistance are part of the relations, they are two sides of the same phenomenon. They work together and cannot function apart. Similarly, support and control exist as part of relations. Support, as well as control, is possible in every action, in every conversation, in every interaction between those who perform the social work.

\section{Social work and compulsory care}

Compulsory care is based on the same ideology as the probation service, and as all social work for that matter. Social work may be described and understood in many ways. Malcolm Payne (1997) has pointed out that social work, as well as the social workers and the clients, are constructed in their context. Payne says that social work takes place in "an organizational context of agencies; that is, associations of people constructed to achieve particular purposes." (Payne, 1997, p. 20) He argues that this is applicable in self-help groups and private practices as well as in authority-based organizations. The purpose of the organization creates the context in which the social worker is created.

No matter what kind of social work we are dealing with, we see the same kind of caring power. In terms of caring power, we may identify both exclusion and inclusion, both help and control. The purpose of compulsory care is to find a way to motivate the misusers to cooperate voluntarily in the treatment and to accept support to break away from their misuse. The misusers are supposed to be cared for and motivated for their own wellbeing so that they can break away from their misuse. The care is a mean of exercising 
power in the ambition of creating normality.

The Swedish social scientist Billinger (2000) has presented a study of the methods used in compulsory care for substance misusers. She studies what social workers are doing when they are doing motivational work. In her thesis, she describes four different institutions and the work done in them, and she concludes that no actions are taken which could be referred to as motivational work. She cannot find anything that differs from other kinds of treatment strategies. She finds actions conducted, which in other contexts would be called treatment, diagnosis, education, upbringing, and so forth, but nothing that can be seen as a special technique.

Billinger's colleague, Ekendahl (2001), studies the clients, the objects of coercion and care. As regards their motivation, he states that three groups of clients can be discerned. They are the unmotivated, the doubtful, and the motivated clients. The members of the first group do not consider their drug use a problem. They want help with practical matters, and they do not see any reason (for them) to be part of the activities in the institution. The doubtful clients consider their drug use a problem, but, in their opinion, compulsory care is inadequate as regards their own situation. Finally, the motivated clients regard their drug use as a serious addiction problem and emphasize that they are powerless and in need of help. The institutions cannot manage any of these groups. Hence, Ekendahl states that the staff has to understand the clients and to identify their motives. In order to do so, there has to be a good relationship between the social workers and the clients, and, according to the clients, that is not possible in this context (Ekendahl, 2001, p. 264). Here we should remember that a motivated client is a client willing to move in the direction of normality. We might say that the three groups are the ones accepting the caring power, the ones in doubt and the ones desisting the caring power.
But we have to understand motivation and the motivational work that is expected to be carried out during the period of compulsory care. If we cannot find it in the actions, the methods or the "treatment strategies", maybe we can find it in the interpretations of the actions.

\section{Motivational work as caring power}

The concept of motivation comes close to the concept of will. To be motivated is to be interested in something, interested in doing something, to change something. But just wanting to change something is not enough. If a drug misuser is considered motivated by a social worker, he wants to stop the misuse, to leave the drugs behind. Motivation is never used as a term for wanting drugs. If you talk about drugs and motivation, you always talk about leaving the drugs - to be motivated is to wish to be "normal".

Within the framework of the language of social work, you can only be motivated to do normal things, to lead a normal life. In that way, motivation is based on the same idea as caring power. The idea that the people in need of help adapt to the demands made by the helper. To be motivated is to follow the rules (Svensson, 2000).

In compulsory care, social workers and others are supposed to do motivational work in order to make misusers wish to be normal. In other words, they should persuade them to want to be normal. One of the most used books in the courses on methods in schools of social work in Sweden is a book by Per Revstedt (1995) called Motivationsarbete, "Motivational work" (Bergmark \& Lundström, 1998). In this book, Revstedt describes clients as either manifestly motivated or latently motivated. That means that either they do want what the social worker wants them to want or that they are not yet aware of the fact that they want it. 
According to Revstedt, there is no person who is not motivated. There are only people who do not know that they are, and the motivational work is meant to make them realize that they are motivated. Revstedt's concept of motivation aims at the individual's internal goals. Motivation is seen as an ambition to lead a life with as high a degree of meaning and self-fulfillment as possible. This ambition summarizes human nature as constructive, purposeful, social and active. The individual's internal goals might be hidden for the social worker, but in order to see possibilities for change, the social worker examines the external conditions.

Revstedt's assumptions are not empirically tested, but they are confirmed by the social workers' expectations. Therefore, his idea about latent and manifest motivation is widespread among social workers. In a coercive setting, especially, this idea supports the task of the social workers' since the clients cannot avoid the social workers in this setting. When social workers believe that rejecting clients are not really rejecting, but rather showing what Revstedt calls a "contact-puzzle" (kontakt-rebus); then the social workers are not open to an understanding of the clients' intentions. If the social workers are supposed to be the main interpreters of the clients' thoughts and will - how might a close relationship then be created?

\section{Individualization or confusion?}

Compulsory care for alcoholics and drug misusers is confusing. If we see the idea of coercion as part of the project of the welfare state, we can understand this form of caring power as a way for the state to take care of the individual at the same time as the individual is being disciplined. It is a way to provide help for individuals who do not realize that they are in need of care. A way to exercise caring power.
When substance misusers do not see the reasons for coercion, it could be seen as a result of repressive rules since the misusers and the coercive system have different views on their interaction. Researchers in Law and Social Sciences have tried to understand the coercion of substance misusers in many ways. They have studied the legislation, the institutions, the history of the legislation and the institutions, the methods used and the actions taken, as well as the views of the staff and of the clients. None of these studies can explain why the coercion of substance misusers does not work out as it is supposed to, even less how it is working. A common conclusion is that it does not work as expected.

Since compulsory care is part of the social engineering in the welfare state and, thus, a kind of social work, we must learn more about the interaction between the social workers and the clients as well as between the clients and the institution, the institution and the legislation, and the clients and the legislation. The system is based on the benevolence of people at all levels. In the studies that have been done, this benevolence often turns out to be a repression.

Could it be that the problem in understanding this is the contradiction between benevolence and oppression, between coercion and care? If we use the concept of caring power, we can get behind this contradiction and see the actions and interpretations as parts of the same caring power. Thus, care is coercive. Social work with substance misusers is based on the idea that a better life is possible. The idea of motivating substance misusers to leave their drugs is a way of persuading them to change in the direction of normality.

We know that when the expectations of the social workers and the clients differ and when they have different views on their mutual task, they describe their interaction as a struggle. We can learn from Elisabeth Fry's work two hundred years ago that giving hope 
to and respecting the clients while supporting them makes it possible for them to adjust. Showing a person respect means that you accept his thoughts and ideas, at least parts of them. To do that, you have to understand the other person and his situation; you have to get to know him. This knowledge accumulates possibilities to exercise power.

The lack of clarity about coercive care is not a confusion. It is a result of ignoring the power involved. Since knowledge is power, and care is power, we have to ask ourselves if we believe that help and support is possible without control. If we believe that to be possible, then we do not take power into consideration. But if we do not believe that to be possible and pay regard to the caring power, then we will be able to discuss compulsory care of drug misusers from another perspective. That perspective leaves the ideological distinction between punishment and treatment behind without ignoring it and, therefore, makes it possible to accumulate knowledge about the relationship between the individual and the institution.

\section{References}

Bergmark, Å. \& Lundström, T. (1998). Socialhögskolorna och metoder i socialt arbete. Socionomens forskningssupplement $n r$ 9, Socionomen, 9, 67-81.

Billinger, K. (2000). Få dem att vilja. Motivationsarbete inom tvångsvården av vuxna missbrukare. Rapport i socialt arbete nr 95. Stockholm: Department of Social Work. Stockholm University.
Björkman, J. (2001). Vård för samhällets bästa. Debatten om tvångsvård $i$ svensk lagstiftning 1850-1970. Stockholm: Carlssons.

Care of Abusers Act 1988: 870.

Van Drenth, A. \& de Haan, F. (1999). The Rise of Caring Power. Elisabeth Fry and Josephine Butler in Britain and the Netherlands. Amsterdam: Amsterdam University Press.

Ekendahl, M. (2001). Tvingad till vård - missbrukares syn på LVM, motivation och egna möjligheter. Rapport i socialt arbete nr 100. Stockholm: Department of Social Work. Stockholm University.

Foucault, M. (1987). Övervakning och straff. Fängelsets födelse. Lund: Arkiv förlag.

Gustafsson, E. (2001). Missbrukare i rättsstaten. En rättsvetenskaplig studie om lagstiftningen rörande tvångsvård av vuxna missbrukare. Stockholm: Norstedts Juridik.

McGowen, R. (1995). The Well-Ordered Prison. In N. Morris \& D. J. Ruthman (Eds.) The Oxford History of the Prison. The practice of Punishment in Western Society. Oxford \& New York: Oxford University Press, 71-99.

Payne, M. (1997). Modern Social Work Theory. (2nd ed.). London: Macmillan Press Ltd.

Perrow, C. (1967). A Framework for the Comparative Analysis of Organizations. American Sociological Review, Vol. 32, No.2, 194-208.

Revstedt, P. (1995). Motivationsarbete. Stockholm: Liber.

Svensson, K. (2000). Motivationsarbetets praktiska ramar. In E. Johnsson, L. Laanemets \& K. Svensson (Eds.). Narkotikamissbruk. Debatt behandling och begrepp. Lund: Studentlitteratur.

Svensson, K. (2001). I stället för fängelse? En studie av vårdande makt, straff och socialt arbete. Lund: Lund University, School of Social Work. 